\title{
QUALITY-SATISFACTION-LOYALTY: CONSUMER BEHAVIOUR IN CATERING
}

\author{
Mária Rudolfné Katona ${ }^{1}$ \& Nándor Komáromi² \\ ${ }^{1}$ BBS CCCT Budapest Business College of Commerce, Catering and Tourism Faculty \\ 9-11. Alkotmány u. Budapest, 1054,E-mail:agrol@t-online.hu \\ ${ }^{2}$ Szent István University, 1.Páter Károlyu.Gödöllö, 2100,E-mail: Komaromi.Nandor@gtk.szie.hu
}

\begin{abstract}
Our study is the result of the initial research of a qualitative and quantitative research consisting of more stages. The survey was made between 2007 and 2013 and specially focused on the satisfaction of Hungarian customers of catering enterprises with hot kitchen as well as on factors influencing satisfaction and customer loyalty. The results proved that a well planned, central strategy cannot be prepared for the whole catering industry as even enterprises with the same profile (warm food kitchen) show significant differences. The most important task for an enterprise is to establish and know its appropriate clientele well in order to suit its services, selection to their requirements.

Our assumption that customers of fast food restaurants, canteens have lower expectations from selection, personal relations, quality of services than customers of restaurants, public houses, wayside inns, brasseries with traditional methods of selling was proven. In the lattest, the main aspect of choosing a 'favourite place' was the quality of human relations, with the special role, besides other customers, of the staff. Establishing unique atmosphere to the liking of customers can be regarded as an important point of the operational strategy.

It was also proven that the majority of regular customers of restaurants are men, coming from the economically active population. Other active users are youngsters, they mainly go to fast food restaurants.

More impersonal advertisements hardly have any effect, while successful word of mouth propaganda can be achieved by consequent, high level work.

Regular customers can be characterized by rather emotional than market-based attachment. Favourite units are mainly preferred because of their atmosphere, relationships with acquaintances and friends, not because of measurable features, selection or prices.

Those visiting catering enterprises with hot kitchen more frequently are more critical and less satisfied, in spite of this, they are reluctant to part from their regular places.
\end{abstract}

Keywords: catering, consumer behaviour, loyalty, satisfaction, regular customer

\section{Introduction}

In our country, the rate of visiting catering enterprises with hot kitchen is much lower than in other countries, exceptions to this are fast food premises and canteens. Hungarian customers mainly insist on specific catering premises on emotional basis, so it is easier to establish their loyalty and it remains more constant.

Hungarian customers are reluctant to open towards novelties. They find it hard to change their regular places even if there are more arguments for changing than against it. Their taste is basically conservative so it is hard to operate such catering unit in a profitable way permanently where unknown, perhaps exotic dishes, beverages of other nations are sold. Hungarians are willing to try novelties, but according to the results of our research, rarely select them to be their regular places. The daily use of catering enterprises with hot kitchen is more characteristic of those being in their active age than of other age groups. The frequency of visits mainly depends on the size discretionary income. Hungarian youngsters prefer fast food restaurants to traditional ones.

We think, revealing the connections between quality, satisfaction and loyalty could provide broad guidelines for the Hungarian catering enterprises with hot kitchen to establish their strategy in order to achieve more profitable operation.

Keeping customers is one of the determining elements of business success. Researches prove (Reicheld, 1996; Oliver, 1999) that the acquisition cost of acquiring a new customer equals five times that of keeping an old customer. Returning customers are less price sensitive, buy more, reaching them 
costs less due to decreasing marketing costs, while they are willing to pay more, to recommend the company to others and to spread the good reputation of the enterprise. (Reicheld, 2000; 2003; Hetesi-Rekettye, 2005).

The question in the focus of our survey is whether satisfied customers return or perhaps dissatisfied ones as well. How strong is the connection with relation to satisfaction and loyalty? In our study we attempt to reveal the specific features of becoming regular customer.

According to Kotler (1988), "customers are satisfied if products suit their previous expectations". Researches of O'Neill and Mattila (2004) prove that "improving customer satisfaction clearly goes with financial advantages, although targeting customer satisfaction obviously generates costs". According to them, satisfaction is a performance evaluation based on previous experience.

The importance of human factor is also emphasized by the comprehensive work of Veres (1998) about service marketing, taking account of the abstract nature of service. Studying the literature of marketing, we experienced that satisfaction in itself does not contribute to the long term profit of enterprises, focus must primarily be put on loyalty. Deming (1986) formulated first that in the future "it will not be enough to have such consumers who are merely satisfied" According to Reicheld (2003), loyalty does not necessarily mean repurchase, rather making the product popular as repeated visit can also be the result of necessity or laziness. In the Hungarian literature mostly Hetesi and Rekettye (2005) dealt with loyalty. Based on their researches, they determined the intention of repurchase, cross purchases, price sensitivity and recommendation to others as the conceptual elements of loyalty. Signing the factors of abandonment (cross purchase, price flexibility) besides repurchase appears as a novelty by them and they regard recommendation to others as a criterion of loyalty.

Loyalty of guests can be functional or emotional (Barnes, 2003). Functionally loyal ones prefer the comfortable location of catering premises, their easy accessibility and favourable opening hours. For emotionally loyal ones comfort is important, but they find it more important to be greeted by their names, chatting with them, obtaining some kind of experience along with their purchase. Although both groups show satisfaction, the functionally loyal group is less insistent.

Customers decide on changing or staying by their evaluation of the service. The sense of higher changing costs (time, money, effort) result in a higher degree of loyalty and the intention of repeated purchase. However, the question arises, what the change cost burden on the user of catering is as he/she hardly has to count with any administrative, financial or relationship changing cost. Does it stimulate loyalty to the catering premise?

Our previous researches showed (Rudolfné-Karakasné, 2008) that satisfaction related to the atmosphere of catering premises has a positive effect on loyalty, which results in favourable world of mouth propaganda. Satisfaction related to human factors is also of primary importance, which emphasizes the role of human resource. Well-qualified colleagues with proper attitude are an invaluable source of establishing customer loyalty.

\section{Material and method}

The research started in 2007 before the economic crisis and was closed by follow-up in the spring of 2013. After setting targets, formulating hypotheses, determining the limits of research, work continued with collecting secondary information. The so-called, ,desktop research" provided a good base for continuing the research. Besides the available Hungarian and foreign language literature, we used, among others, the research results of $\mathrm{KSH}$ (Hungarian Central Statistical Office) and GFK Hungária as well as on-line information systems.

During our primary research we applied qualitative and quantitative techniques as well. In order to formulate hypotheses precisely, we made deep interviews with knowledgeable professionals individually, which were followed by two interviews with focus groups. we did one of them with the participation of the students of BBS CCCT, who often use catering with hot kitchen; the members of the other group were middle aged, mostly graduated people, who rarely use restaurant catering. Due to an R\&D work, interviewers asked 120 enterprises dealing with catering based on a detailed questionnaire developed by me.

We developed a questionnaire for quantitative research by the application of the results of qualitative researches. In order to filter errors, test interviews, then pilot-interviews were made in the range of BBS CCCT students (150 persons).

For easier completion, we applied mostly closed, selective questions (Likert scale) so processing (coding, data recording, evaluation) was also easier.

For the first time, the questionnaire was filled in by 541 persons in evaluable form. The research was oriented on Hungarian customers exclusively. In the cover letter, we called the attention of the interviewees to the fact that if they hardly ever use catering premises with hot kitchen, they should only provide their personal data. The questionnaires of the first completed survey were printed or sent by e-mail. We applied SAS programme for processing.

During follow-up 339 evaluable questionnaires were created, all of which we transmitted by the programme kérdöivem.hu. We also received the data sheets of processing by this programme. We applied the method of snowball during both surveys.

The results of the initial quantitative research are recorded in this study.

\section{Results}

\section{Criteria of interviewees}

The ratio of women compared to the whole population is $5 \%$ more than that of men according to the demographic data of the $\mathrm{KSH}$, however, in the case of the customers of 
catering premises, the ratio of men and women is $2 / 3-1 / 3$. In the strategy of catering enterprises it is worth paying more attention to women as a new target group, thus increasing the number of customers.

Table 1. Distributions according to age groups (\%) $(\mathrm{n}=541)$

\begin{tabular}{|c|c|c|}
\hline Age group & Population & Questionnaire \\
\hline $0-18$ & 19.95 & 0.74 \\
\hline $19-25$ & 9.10 & 39.56 \\
\hline $26-35$ & 16.06 & 22.92 \\
\hline $36-50$ & 19.65 & 18.30 \\
\hline $51-62$ & 16.79 & 14.97 \\
\hline $63-75$ & 12.08 & 2.59 \\
\hline $76-X$ & 6.36 & 0.92 \\
\hline Total & 100.00 & 100.00 \\
\hline
\end{tabular}

Source: own edition

The respondents of the questionnaires represent the age composition of the whole Hungarian population (table 1.) well. More significant difference was shown in three age groups. The ones under the age of 18 do not have their own income and rarely decide on the selection of premises, while members of the age group over 63 years are typically retired, thus they do not have sufficient discretionary income for the use restaurant catering. The higher ratio of those between 19 and 25 years is due to more simple accessibility and more regular attendance of premises (fast serving premises, pizzerias).

Table 2. Distributions according to educational levels (\%) $(\mathrm{n}=541)$

\begin{tabular}{|l|c|c|}
\hline \multicolumn{1}{|c|}{ Educational level } & Population & Questionnaire \\
\hline Primary school & 39.22 & 0.92 \\
\hline Vocational school & 23.93 & 8.13 \\
\hline Maturity exam & 22.56 & 44.73 \\
\hline College, university & 14.29 & 46.21 \\
\hline Total & 100.00 & 100.00 \\
\hline
\end{tabular}

Source: own edition

The ratio of graduates from secondary and high education is much higher between the respondents of the questionnaires compared to the total Hungarian population (table 2.). With their higher incomes, they are the ones who rather purchase restaurant meals. The ones with lower education, due to their more modest wages and different consumer habits, attend catering premises with hot kitchen only very rarely, thus, in their case, we cannot even speak about loyalty.

Nearly half of the respondents of our analysis lived in Budapest or near Budapest (table 3.), which enabled me to obtain replies relevant to the topic. Already the qualitative examinations showed a greater extent of increase in the number of restaurants, thus the number of favourites with the size of the towns than of the increase of the population figures.
Catering premises with hot kitchen, which form the basis of this survey, can mainly be found in larger towns. $30 \%$ of the Hungarian population live in villages, where we could hardly find such business profiles so our survey is not valid thereto.

Table 3. Regional distribution (\%) $(\mathrm{n}=541)$

\begin{tabular}{|l|c|c|}
\hline \multicolumn{1}{|c|}{ Regional distribution } & Population & Questionnaire \\
\hline $\begin{array}{l}\text { Budapest and its } \\
\text { surroundings }\end{array}$ & 24.50 & 48.06 \\
\hline $\begin{array}{l}\text { Large town in the } \\
\text { countryside }\end{array}$ & 19.62 & 20.33 \\
\hline Small town & 25.42 & 20.70 \\
\hline Village & 30.47 & 10.91 \\
\hline Total & 100.00 & 100.00 \\
\hline
\end{tabular}

Source: own edition

While only $38 \%$ of the Hungarian population are employees, nearly $53 \%$ of our respondents were such (table 4.) Those who most often attend catering premises with hot kitchen are employees, thus we could rely on evaluable replies based on this aspect.

Table 4. Distributions according to economic activities (\%) $(\mathrm{n}=541)$

\begin{tabular}{|c|c|c|}
\hline Economic activity & Population & Questionnaire \\
\hline employed & 38.10 & 52.87 \\
\hline unemployed & 4.60 & 1.11 \\
\hline inactive wage-earner & 30.50 & 9.06 \\
\hline dependent & 26.70 & 36.97 \\
\hline \hline Total & 100.00 & 100.00 \\
\hline
\end{tabular}

Source: own edition

An important target group of the catering premises consists of such students in higher education who also do gainful activities besides their studies. Households of respondents containing three-four persons represent higher ratios compared to the resident population. Based on this it can be stated that mostly single ones go to the catering premises under survey.

\section{Distribution of catering premises according to their character}

One of our hypotheses, that is, Hungarians are quite conservative in gastronomy, was proven by the examination of the character of catering premises. Nearly $60 \%$ of respondents prefer traditional places, one fifth of them signed Hungarian style catering premises. The smallest ratio (13\%) contained those preferring the cuisine of other nations, while number of votes on special (e.g.: thematic) premises was negligible. Insisting on usual, tried flavours makes the establishment of Hungarian clientele in restaurants with special flavours more difficult. 
The replies of respondents show that restaurant is the most preferred, that is, 'favourite' business profile within the catering business circle with hot kitchen. Just over half of the respondents voted on this. The proportion of restaurants and brasseries with more family-like atmosphere is $12 \%$ and $10 \%$, cafes represent $7 \%$, while wayside inns, cookshops, fast food premises have $19-20 \%$ of the replies. Based on these, it can be rightly concluded that most of the respondents selected better quality catering premises providing higher level of services to be their favourite premises. However, we assume that these catering premises serve not the daily eating requirements of their Hungarian users, their attractions derive rather from celebrations, events and companies.

We also asked where they learnt about the premises that later became their favourites. The answers showed that advertisements and others communication devices did not achieve the desired effect, total proportion thereof is less than 5\%. Thus, it is to be considered by catering professionals whether it is worth spending significant amounts on advertisements. However, in the case of new, high level restaurants, publicity is important in the initial part of their lifecycles, we suggest the use of active marketing activity.

Regarding favourite catering premises, nearly half of the respondents were recommended the signed enterprises with hot kitchen, that is, word of mouth propaganda worked well. It can be supported by figures that a prospective customer is most influenced about his selection by another customer who has already been to the premise, which must motivate the profession to provide the best and most hospitable catering. To err is not possible, as word of mouth propaganda is even stronger in creating negative publicity. $45 \%$ of the respondents decided based on the aspects of comfort (they live or work near), they are functionally loyal, that is, they become regular customers to a lesser extent or more slowly.

Data received to our question regarding the regularity of attendance are also not encouraging for the future of the profession. $73 \%$ of respondents use catering enterprises on monthly basis or even more rarely and only $6 \%$ eat in them daily. Making attendance more frequent is hindered by the price sensitivity of Hungarian customers as well as by their preference of home meals.

\section{Connections between satisfaction, loyalty and relationship}

The second large unit of the questionnaire contained the detailed survey of customer opinions. we expected evaluation to 35 statements, 14 thereof referring to satisfaction, 6 to loyalty and 15 to relationships. Respondents had to rank them in compliance with school grading (Likert scale, 1-5).

\section{Answers of customers to the subject of 'satisfaction'}

Statements of the topic of satisfaction (table 5.) refer to catering premises with hot kitchen, thus the number of negative opinions deriving from dissatisfaction is insignificant.
Table 5. Statements of the topic of satisfaction

\begin{tabular}{|c|l|}
\hline 1 & Staff is friendly, attentive \\
\hline 2 & Staff/management cares about my requirements \\
\hline 3 & Speed of service \\
\hline 4 & Selection of food and beverages \\
\hline 5 & Quality of food \\
\hline 6 & Proper price/quality ratio \\
\hline 7 & Services: music, private room, reservation \\
\hline 8 & Accessibility of catering premise \\
\hline 9 & Availability of car parking \\
\hline 10 & Environment, external view of catering premise \\
\hline 11 & Atmosphere of restaurant (furniture, interior design) \\
\hline 12 & Cleanness of place \\
\hline 13 & Opening hours of catering premise \\
\hline 14 & Clientele \\
\hline
\end{tabular}

Source: own edition

When customers provided their opinions about their favourite places, the number of indifferent and satisfied replies besides the expected very satisfied appeared with surprising frequency, related mostly to the environment and prices. More than half of the customers were very satisfied with the staff. Considering satisfaction, the atmosphere of catering enterprises and the attitude of their staffs proved to be much more important than quality, selection or prices.

\section{Results of the topic of 'loyalty'}

By the statements of the subject of loyalty (table 6.), we examined the loyalty of customers (table 7.) and their marketbased approach (table 8.). In the latter case, we were searching the reply to how much benefiting from market advantages, that is, prices and offers of competitors, matters.

Table 6. Statements of the topic of loyalty

\begin{tabular}{|c|l|}
\hline 1 & Consider myself a loyal guest (regular customer) here. \\
\hline 2 & Even if its prices were risen, i would remain its guest. \\
\hline 3 & $\begin{array}{l}\text { If a competitor offered more favourable prices or discounts, } \\
\text { i would select that one. }\end{array}$ \\
\hline 4 & $\begin{array}{l}\text { In the near future - if i could afford it - i would visit this place more } \\
\text { often. }\end{array}$ \\
\hline 5 & It is important to me to select the catering unit, which is near to me. \\
\hline 6 & It is important to me to select one with suitable quality. \\
\hline
\end{tabular}

Source: own edition

By the survey from the aspect of their loyalty, nearly one quarter of customers consider themselves loyal, 27-28\% of them are indifferent to the question and merely $1.5 \%$ do not consider themselves absolutely loyal. In contrast with this, $45 \%$ of respondents are indifferent to, while $18 \%$ of them categorically reject market-based approach. We can state that customers insist on their favourite catering premises much more on emotional basis than rationally. 
Table 7. Loyalty

\begin{tabular}{|c|c|c|}
\hline Loyalty & Frequency & Percentage (\%) \\
\hline \hline 1 & 0 & 0.00 \\
\hline 2 & 8 & 1.48 \\
\hline 3 & 148 & 27.36 \\
\hline 4 & 283 & 52.31 \\
\hline 5 & 102 & 18.85 \\
\hline Total & 541 & 100.00 \\
\hline
\end{tabular}

Source: own editio

Table 8. Market-based approach

\begin{tabular}{|c|c|c|}
\hline Market-based approach & Frequency & Percentage (\%) \\
\hline 1 & 21 & 3.88 \\
\hline 2 & 78 & 14.42 \\
\hline 3 & 244 & 45.10 \\
\hline 4 & 161 & 29.76 \\
\hline 5 & 37 & 6.84 \\
\hline Total & 541 & 100.00 \\
\hline
\end{tabular}

Source: own edition

\section{Research of "relationships" between interviewees}

Table 9. contains statements referring to the survey of the importance of relationships. Based on the replies it is shown that the personal, emotional insistence of customers on their favourite catering premises is much stronger than their market-based approach, although there is a considerable variation between their opinions.

Table 9. Statements of the subject of relationships

\begin{tabular}{|c|l|}
\hline 1. & Staff/management knows me well. \\
\hline 2. & $\begin{array}{l}\text { My relationship with my favourite premise is very } \\
\text { important to me. }\end{array}$ \\
\hline 3. & $\begin{array}{l}\text { Maintaining my relationship is worth every effort (time, distance, } \\
\text { travel, etc.) }\end{array}$ \\
\hline 4. & I am very cautious about selecting new catering premises. \\
\hline 5. & I like trying new, unknown things, just for a change. \\
\hline 6. & I constantly compare catering units in similar categories. \\
\hline 7. & $\begin{array}{l}\text { The attractiveness of my catering premise had a great role in my } \\
\text { selection of this unit. }\end{array}$ \\
\hline 8. & $\begin{array}{l}\text { I had visited more similar catering premises before selecting this } \\
\text { one. }\end{array}$ \\
\hline 9. & Selecting a good catering premise is an important decision to me. \\
\hline 10. & The catering premise I am customer of reveals a lot about me. \\
\hline \hline 11. & $\begin{array}{l}\text { After selecting this place, I was considering the advantages and } \\
\text { disadvantages of my decision. }\end{array}$ \\
\hline 12. & It is important to me to be able to meet my friends here. \\
\hline 13. & $\begin{array}{l}\text { Here I can also meet such people (e.g.: business relations) who are } \\
\text { important to me. }\end{array}$ \\
\hline 14. & My family members/friends also enjoy being here. \\
\hline 15. & $\begin{array}{l}\text { I would kindly recommend this place to my friends, colleagues and } \\
\text { their families. }\end{array}$ \\
\hline
\end{tabular}

Source: own edition
We classified the replies received to the above statements into five logical groups (order number of statements is shown between the brackets):

1. character of regular place (2-3)

2. friendly, business relationships (12-15)

3. selection of favourite place (4-9)

4. prestige (10-11)

5. personal relationship (1)

Figure 1. shows the compounds of the relationship.

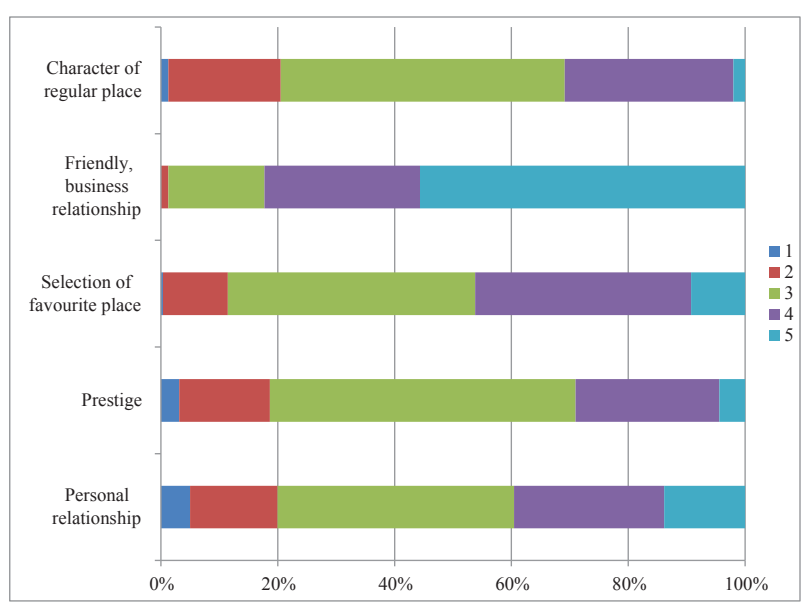

Figure 1. Components of the relationship in the case of a favourite place

Based on the scale ( 1 very much does not agree, 2 does not agree, 3 indifferent, 4 agrees, 5 very much agrees) it can be stated that the ratio of those regarding the indicated five aspects important is higher in every case than that of those who feel it less important. Creating ranking: customers regard prestige and maintaining relationship with their regular places the least determining. It is followed by personal relationship, then the two points considered most important in the field of relationships: the thoroughness of selecting favourite places as well as friendly and business relationships (according to $82 \%$ they are important and very important). They regard the most significant that their family members and friends also feel good there and they gladly recommend the catering premise to their friends, colleagues and families. Thus, a catering premise can obtain more customers not by indirect and at the same time more impersonal advertisements, but by transmitting satisfied and loyal clientele.

\section{Correlations between the opinions of customers and their objective features}

In order to reveal correlations, we examined twodimensional cross tables that were necessary to differentiate between the subjects of satisfaction, loyalty and relationships based on the features of customers and catering premises. The previous one contained eleven variables ( satisfaction with staff; prices; service, selection, quality, atmosphere; accessibility, environment; loyalty; market-based approach; personal relationship; prestige; selection of favourite place; character of regular place; friendly, business relations) the 
latter contained twelve criteria (type, town, character, category, recommendation, regularity of attendance of catering premise, gender, age, educational level, economic activity, income and residence of customer). This, in itself, would have meant 132 different tables, the number of which had to be reduced to the ones containing relevant information. (We applied the formulas of Pearson, Csuprov and Cramer, details thereof are excluded from this study.)

Based on the cross tables obtained from the questionnaires, we concluded that in the case of restaurants and cafes, the atmosphere of the catering premise, quality, selection of food and beverages are much more important than in other cases. (figure 2.) These are the least important factors in the case of cookshops, which can be explained by the differences of the characteristics of the enterprises.

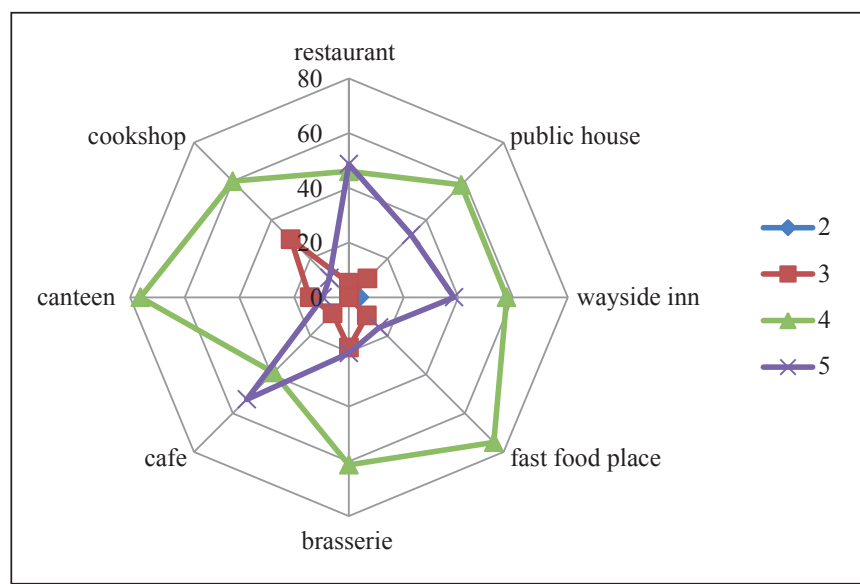

Figure 2. Selection, quality, atmosphere

We can examine in a similar way how important customers regard enterprises being regular places according to their character. It can clearly be determined that it is not relevant in the case of cookshops, fast food premises, but relevant in the case of cafes, restaurants, brasseries, public houses and wayside inns. These are such catering premises that customers attend not for fast, inexpensive eating, but their companies and the places themselves have priority here.

Friendly, business relations (figure 3.) are the most important also in the case of brasseries, restaurants and cafes, while in the case of such places offering specially 'only' hot meals and alcohol-free beverages (cookshops, canteens and fast food restaurants), they are irrelevant.

Catering premises with hot kitchen can be divided into two groups based on their character. The first group contains canteens, cookshops, fast food premises, where the expectations of customers are much more modest. We classified restaurants, brasseries, cafes, wayside inns and restaurants into the second group. Here social relationships, friendly atmosphere, regular place character are much more important, by which, in parallel, quality and atmosphere also become more significant.

We analysed, unlike before, the connection between the way of learning about catering premises and the market-based attitude of customers not by percentage lines, but by the percentages of the cells of cross tables compared to the total population. It is visible that most customers selected their favourite places by using their relationships, although the vicinity of their residences or workplaces can also be regarded significant. Market-based approach is a characteristics of those who select their regular places on the basis of advertisements or good accessibility. They can be much more influenced by competitors than those attached to a given catering premise by their social relationships.

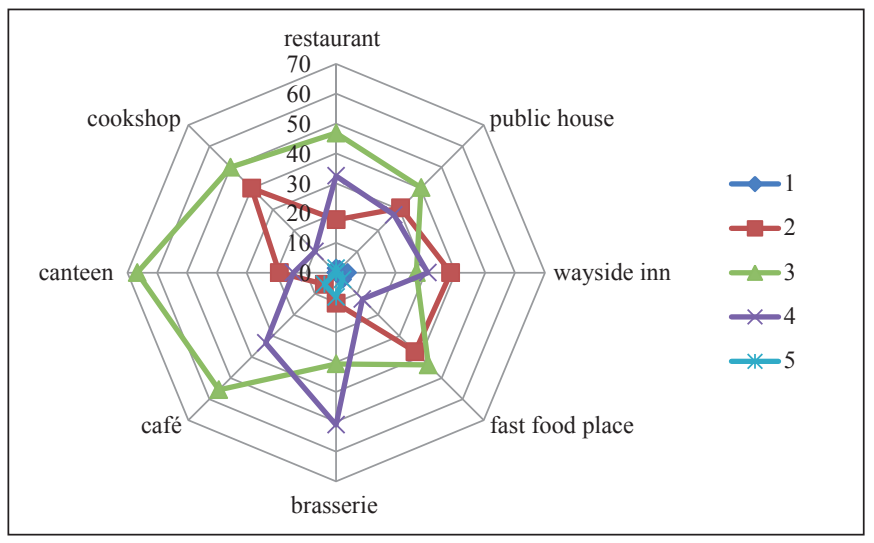

Figure 3. Friendly, business relations

Examining the frequency of the attendance of catering premises, we received the interesting result that those who often attend their favourite catering premises are less satisfied and they are also more critical towards staff. Maintaining relationships with other customers is much more important than satisfaction with staff. Based on the analysis, the same can be said about the examination of the frequency of attendance with relation to service, prices, selection, quality, atmosphere and accessibility. Those who attend regularly are more dissatisfied than those who rarely use the service or only on special occasions. The 'conservatism' of customers, that is, insisting on the usual, can be detected here as well. The feeling of insecurity originating from changing/change is stronger than the role of advantages that can possibly be obtained therefrom.

Regular customers find it important to be welcomed by the staff, owner or manager of the enterprise, to be greeted by their names and to take care of their personal habits.

By regular attendants relationships maintained with other customers, staff or management are more important than their satisfaction with the performance of the restaurant. It can be also determined from our data that this is true only over a certain 'threshold performance level'. By the decreasing regularity of attendance, satisfaction with prices, services and selection becomes more important than personal relationships.

It is also interesting to examine the role of prestige (figure 4.). Whether customers select those catering premises they think reveal the most of them? According to our analysis, this is not equally strong by the examined age groups, it is the most significant in the case of 36-50 year old ones. This is understandable as they already have their established status and lifestyle to which, in a good case, they have created the necessary financial conditions and they would not like to belong to somewhere beyond their power. In case of youngsters 
under the age of 25, prestige is less important, than it is for older age groups. During the research more times, however, by this question definitely occurred to me that respondents formulated 'shaded' replies trying to achieve an image that seemed ideal to them. In our experience, prestige has a much greater role in catering than it was reflected by our data.

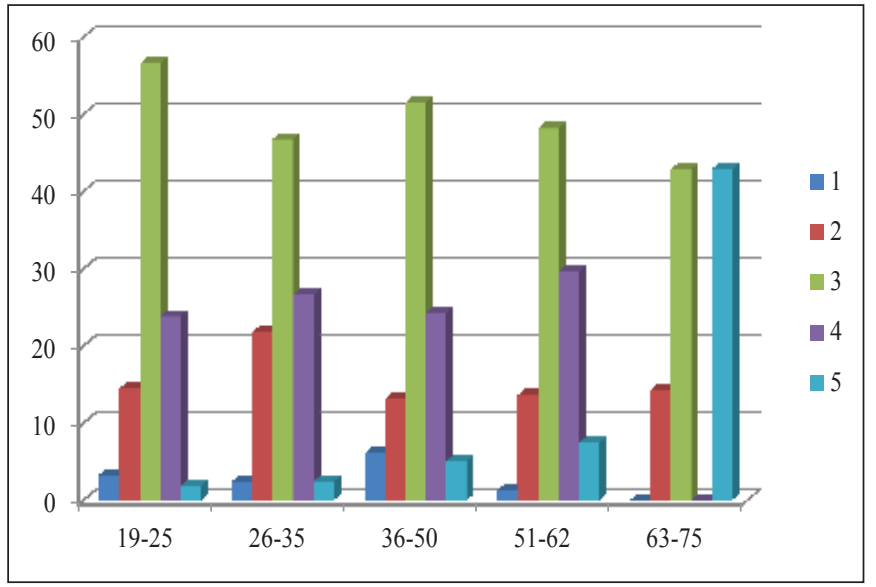

Figure 4. Prestige

Our research showed that in case of wages equivalent to or near minimum wage per person, selection, quality and atmosphere are not significant, however, approaching to higher levels of income, their significance increases. In case of connections between the importance of regular place character and size of income it can be stated that higher earnings attract higher requirement levels.

\section{Conclusions}

Based on research results it was proven that such a well planned, central strategy like in the case of tourism cannot be prepared for the whole of catering industry as even enterprises belonging to the same profile with hot kitchen differ from each other significantly. However, guidelines can be sketched, providing support for the establishment of a strategy targeting the increase of consumption and more profitable operation.

The questionnaire-based survey showed that mostly men attend catering units with hot kitchen regularly so the less active gender of women can be aimed at as a new target group. Such tools and methods must be invented, by which they can also be 'attracted' to catering premises with hot kitchen.

Regular attendants of catering units mostly come from the economically active population, but the partly dependent and partly earner students of higher education also possess a significant volume, thus, we must know and suit their requirements better.

Our assumption that customers of fast food restaurants, canteens have lower expectations from selection, personal relations, quality of services than customers of restaurants and cafés was proven. By the latter ones, human relationships are the most important factor when selecting 'favourite place'.
It is understandable that more impersonal advertisements hardly contribute to the increase of the turnover of catering enterprises. It is proven that more efficient word of mouth propaganda can be achieved by consequent, high level work, which significantly influences the selection of enterprises.

Regular customers can be characterized by rather emotional than market-based insistence. Favourite units are mostly preferred because of their atmosphere, relationships with acquaintances, friends than because of measurable things, for example: selection or prices. Such customers loyal to the enterprise more often attend those, where they also have emotional attachment.

The examination of the frequency of attendance led to an interesting result as well. It was revealed that more frequent attendance results in more critical contemplation. Based on the replies it can be determined that those who attend a given catering enterprise more regularly are more dissatisfied with the staff than those attending it less frequently. Personal contacts, relationship between customers and caterers have significant importance. Customers require care, thus establishing emotional, personal attachment is necessary.

The existing, loyal clientele of a catering premise has significant role in joining potential customers. In our next research we would like to prove how determining is the ratio of regular customers as well as the presence of such persons having central and linking role in the life of catering enterprises.

\section{References}

Barnes J. (2003): Establishing meaningful customer relationships: why some companies and brands mean more to their customers, Managing Service Quality, Vol. 13, p 178-186.

Deming W. E. (1986): Out of the Crisis, Cambridge, MA: Massachusetts Institute of Technology Center for Advanced Engineering Study (In: Oliver, 1999)

Hetesi E. \& Rekettye G. (2005): Longitudinal measuring of the dimensions of loyalty in the range of Hungarian energy consumers based on factor analysis. Vezetéstudomány, 2005/III. p 48-57.

Kotler P. (1998): Marketing management, Müszaki Könyvkiadó, Budapest p 875.

O'Neill J. W \& Mattila A. S. (2004): Connection between brand building strategy and customer satisfaction as well as revenue from rooms, Journal of Hospitality \& Tourism Research 2004/2. -

Oliver, R. L. (1999): Whence Consumer Loyalty?, Journal of Marketing Vol 63 p 33-44.

Reicheld, F. F. et al. (2003): Loyalty: A Prescription for Cutting Costs, Marketing Management, 2003. Vol. 12

Reicheld, F. F. (1996): Learning from Customer Defections, Harvard Business Review, 96, Vol. 74.

Reicheld F. F. (2000): The Loyalty Effect - The Relationship between Loyalty and Profit, Europian Business Journal, 2000/III. p 134-139.

Rudolfné Katona M., Karakasné Morvay K. \& Magyar M. (2008): Measuring the quality of service and customer satisfaction, AGORA, BGF KVIK, Budapest, p 38-46.

Veres Zoltán (1998): Service marketing, Műszaki Könyvkiadó, Budapest

Zeithaml-Parasuraman-Berry (1990): Delivering Quality Service; Balancing Customer Perceptions and Expectations, Free Press, p 99. 